\title{
Adventitious shoots from nodule cluster cultures of Vriesea reitzii: an endemic and endangered bromeliad from atlantic forest
}

\author{
Brotos adventícios a partir de culturas nodulares de Vriesea reitzii: uma bromélia endêmica e em \\ extinção da Mata Atlântica
}

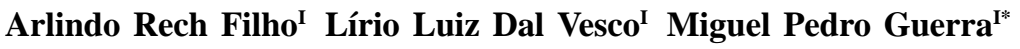
\begin{abstract} and a number of bromeliads take part of it. This is the case of Vriesea reitzii, an endemic bromeliad threatened with extinction. Tissue culture techniques are valuable tools for the mass propagation of bromeliads, thus reducing pressure in the natural habitat. The aim of the present work was to establish an in vitro protocol based on the induction and proliferation of nodule cluster cultures of this species. Plantlets maintained in MS liquid culture medium plus NAA $(2 \mu M)$ and BAP $(4 \mu M)$ had the basal regions of leaves excised and then inoculated in gelled with agar $\left(7 \mathrm{~g} \mathrm{~L}^{-1}\right)$ MS culture medium plus with Dicamba $(2.5 ; 5 ; 10 ; 20$ e $30 \mu \mathrm{M})$ and $\mathrm{Kin}(2 \mu \mathrm{M})$ or free of plant growth regulators. Nodule cluster cultures arose from the basal region of explants. The subculture to MS liquid medium plus GA $(10 \mu M)$ and in MS liquid medium free of plant growth regulators resulted in a high proliferation rate. The mean regenerative rate was 39 plantlets $/ 0.03 \mathrm{~g}$ of nodule culture. Plantlets were acclimatized in a mix substrate of 1:1 (v:v) of carbonized rice coat and Turfa Fertil ${ }^{\circledR}$ mineral supplement.
\end{abstract}

Key words: bromeliads, microshoots, in vitro regeneration, conservation, acclimatization.

\section{RESUMO}

A floresta tropical atlântica é um bioma de alta diversidade, rico em espécies endêmicas de bromélias, entre elas Vriesea reitzii, que se encontra ameaçada de extinção. Técnicas de cultura de tecidos possibilitam a propagação massal de bromélias, reduzindo a pressão de coleta na natureza. O presente trabalho teve como objetivo desenvolver um protocolo regenerativo baseado na indução $e$ no desenvolvimento de culturas nodulares desta espécie. Plantas multiplicadas em meio MS líquido com ANA $(2 \mu \mathrm{M})$ e BAP $(4 \mu M)$ tiveram suas folhas excisadas e inoculadas em meio MS geleificado com ágar $\left(7 \mathrm{~g} \mathrm{~L}^{-1}\right)$ e suplementado com Dicamba $(2,5 ; 5 ; 10 ; 20$ e $30 \mu \mathrm{M})$ e Kin $(2 \mu \mathrm{M})$ ou isento de fitorreguladores. A indução de culturas nodulares foi observada na região basal dos explantes. Estas culturas foram subcultivadas em meio de cultura MS líquido suplementado com GA $(10 \mu \mathrm{M})$ e subseqüentemente para meio MS líquido isento de fitorreguladores, resultando em altas taxas de proliferação de culturas nodulares que originaram brotos adventícios e microbrotos. A taxa média de regeneração foi de 39 brotos $/ 0,03 \mathrm{~g}$ de culturas nodulares. As mudas foram aclimatizadas com sucesso em substrato composto por fertilizante organomineral Turfa Fértil ${ }^{\circledast}$ e casca de arroz carbonizada na proporção de 1:1 (v:v).

Palavras-chave: bromélias, microbrotos, regeneração in vitro, conservação, aclimatização.

The Brazilian Atlantic biome contains high genetic diversity and endemic species. Bromeliads are important components of this biome and among them V. reitzii, an endemic and endangered bromeliad. This species occurs in regions with altitudes from $750 \mathrm{~m}$ to $1200 \mathrm{~m}$ in the states of Santa Catarina, Paraná and Rio Grande do Sul (REITZ, 1983), and reveals excellent potential as ornamental (Figure 1a). The ecosystem in which this bromeliad is distributed, the Araucarian Mixed Forest, was severely devastated during the last century.

The in vitro morphogenesis in bromeliads from different explant sources has been associated with organogenesis in Vriesea fosteriana (MERCIER \& KERBAUY, 1992). In Dyckia distachya in vitro culture

\footnotetext{
IPrograma de Pós-graduação em Recursos Genéticos Genéticos Vegetais, Universidade Federal de Santa Catarina (UFSC), Florianópolis,
} SC, Brasil. E-mail: mpguerra@cca.ufsc.br. *Autor para correspondência. 


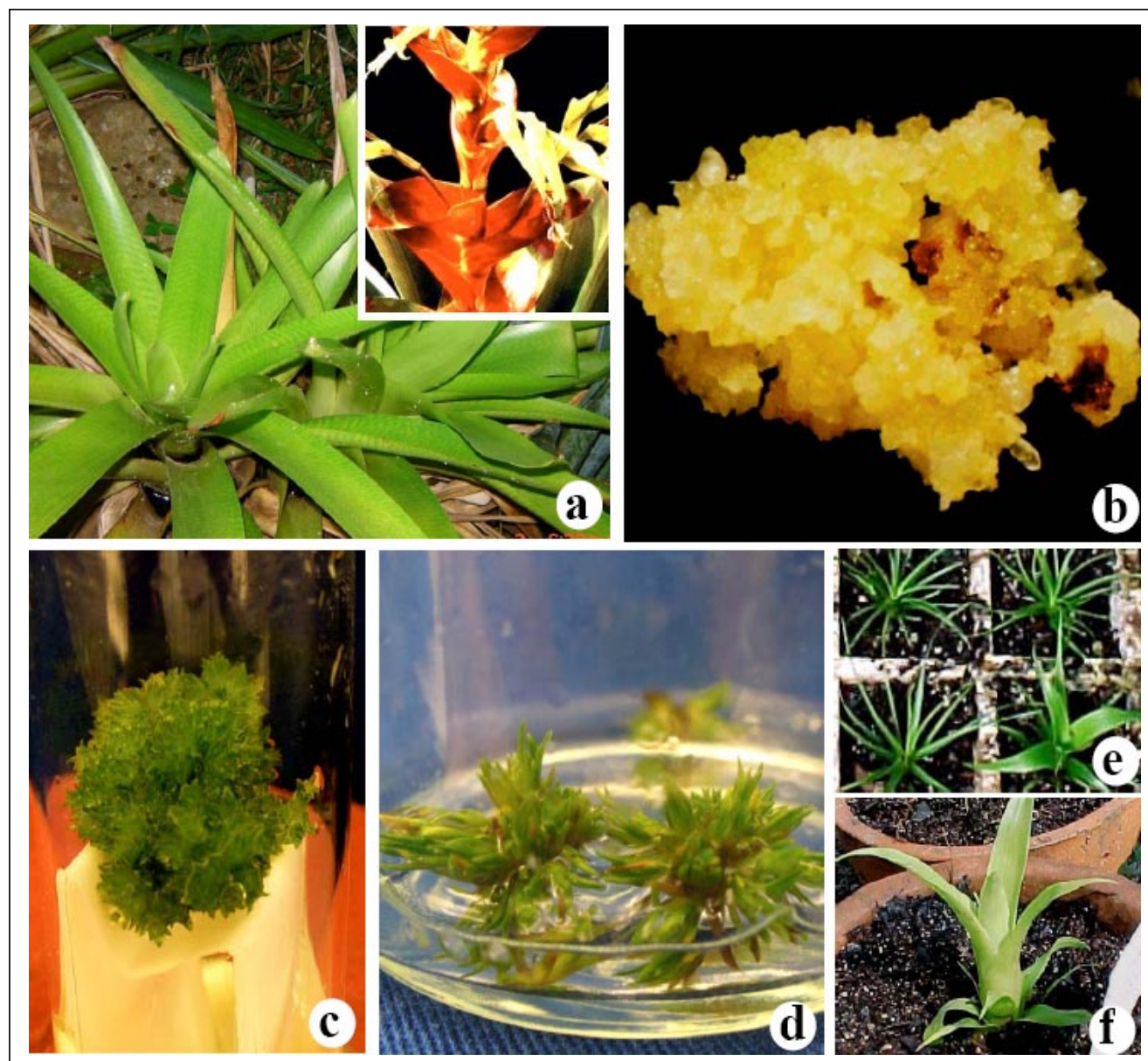

Figure 1 - Nodule cluster culture formation and shoot regeneration in V. reitzii. a) Donor plant, see in detail inflorescence of adult plant; b) Yellow nodular cluster cultures induced in MS medium free of PGR; c) Nodule cluster subcultured in MS culture medium supplemented with $\mathrm{GA}_{3}(10 \mu \mathrm{M})$ resulted in high proliferation rate and the subsequent development of adventitious microshoots; d) Elongation and growth of shoot in MS culture medium free of PGR; e) Acclimatization of plantlets; f) growth in greenhouse. CCA/UFSC, 2004

allowed the mass regeneration for conservation purposes (POMPELLI \& GUERRA, 2005). In Vriesea friburgensis microbuds were induced from plantlets (ALVES \& GUERRA, 2001). Microbuds were also observed in V. reitzii (RECH FILHO et al., 2005). ALVES et al. (2006) showed that the leaf basal region of $\boldsymbol{V}$. reitzii was competent for the long-term regeneration and multiplication of nodule cluster cultures induced in MS culture medium supplemented with 2,4-D - 2,4dichlorophenoxyacetic acid $(20 \mu \mathrm{M})$.

The present research describes the establishment of an in vitro regenerative protocol based on nodule cluster cultures aiming at the mass propagation and conservation of $\boldsymbol{V}$. reitzii. Basal leaves were excised from shoots cultured in vitro in MS culture medium (MURASHIGE \& SKOOG, 1962) plus $2 \mu \mathrm{M}$ of naphtaleneacetic acid (NAA) and $4 \mu \mathrm{M} 6$ - benzylaminopurine (BAP). For the induction phase explants were inoculated in Petri dishes containing $15 \mathrm{~mL}$ of MS culture medium gelled with agar $\left(7 \mathrm{~g} \mathrm{~L}^{-1}\right)$. The basal MS culture medium free of plant growth regulators (PGR) was used as control and this same basal medium was supplemented with Dicamba - 3,6dichloroanisic acid $(2.5 ; 5 ; 10 ; 20$ and $30 \mu \mathrm{M})$ and Kinetin (Kin, $2 \mu \mathrm{M}$ ) composing the different treatments. The experimental design was completely randomized blocks with three replicates. Each experimental unit was constituted of four Petri dishes containing five explants (60 explants per treatment). Nodule cluster cultures ( $0.03 \mathrm{~g}$ fresh weight) were subcultured to test tubes over paper filter bridges. Three different culture media were tested: 1) MS free of PGR; 2$)$ MS plus NAA $(2 \mu \mathrm{M})$ and BAP $(4 \mu \mathrm{M})$, and; 3 ) MS plus giberellic acid ( $\mathrm{GA}_{3}$, $10 \mu \mathrm{M})$. Microshoots derived from the previous phase 
were subcultured in $300 \mathrm{~mL}$ glass flasks containing $20 \mathrm{~mL}$ of liquid MS culture medium free of PGR. The plantlets were subcultured for more 60 days in MS culture medium PGR free. Plantlets longer than $2.5 \mathrm{~cm}$ were acclimatized in trays with 72 cells $\left(120 \mathrm{~cm}^{3}\right)$ containing a substrate of $1: 1(\mathrm{v}: \mathrm{v})$ of carbonized rice coat and Turfa Fertil ${ }^{\circledR}$ mineral supplement $\left(\mathrm{N}-4, \mathrm{P}_{2} \mathrm{O}_{5}-\right.$ $\left.14, \mathrm{~K}_{2} \mathrm{O}-8\right)$

The resulting in vitro morphogenetic route is summarized in the Figure 2. MS medium PGR-free promoted the induction of nodule cultures (Figure 1b) with high proliferation (Table 1). Nodule cultures resulting from MS culture medium supplemented with Dicamba and Kin showed low proliferation, most of them with necrosis, mainly in response to high levels of Dicamba (Table 1). This PGR is commonly employed in agriculture as herbicide. However, when employed in low levels in the tissue culture of monocotyledons it shows remarkable morphogenic effects (GEORGE, 1993).
Nodule cultures subcultured in MS liquid medium with $\mathrm{GA}_{3}(10 \mu \mathrm{M})$ showed proliferation of microshoots (Figure 1c). When these microshoot clusters were subcultured to glass flasks $(300 \mathrm{ml})$ containing liquid MS culture medium free of PGR a high proliferation rate and the subsequent development and elongation of multiple adventitious shoots were observed (Figure 1d). Each $0.03 \mathrm{~g}$ of the nodule cluster culture yielded a regeneration rate of 39 shoots (Data not shown). Plantlets $2.5 \mathrm{~cm}$ long were transferred to trays filled with the substrate described previously. The survival rate of acclimatization was $100 \%$ (Figure 1e).

The in vitro morphogenesis in bromeliads shows specific features. In $\boldsymbol{V}$. fosteriana (MERCIER \& KERBAUY, 1992) these structures were denominated cell masses. In $\boldsymbol{D}$. distachia, a threatened endemic bromeliad of South Brazil, a regenerative protocol was successfully developed for the in vitro conservation and mass propagation (POMPELLI \& GUERRA, 2005).

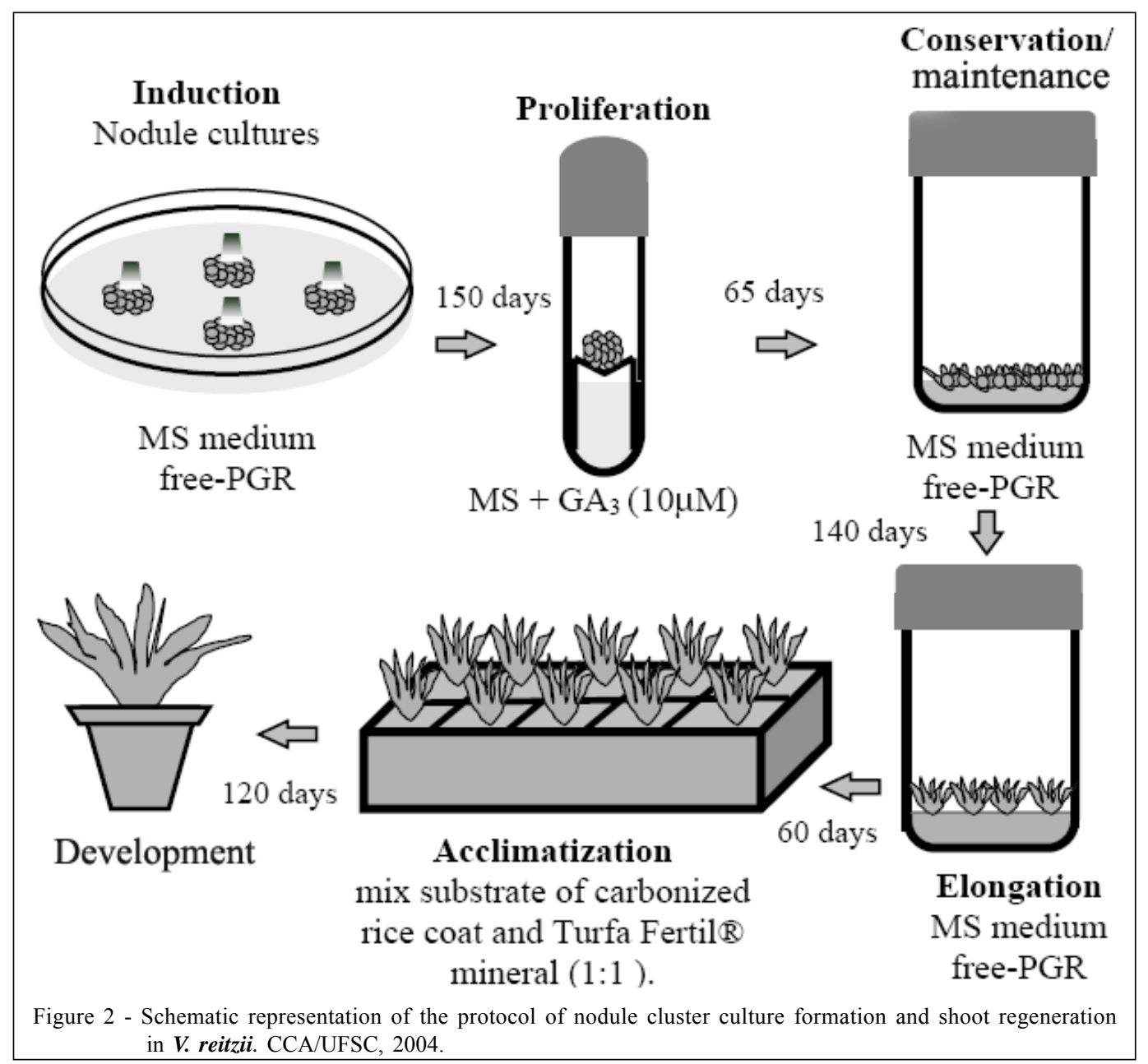

Ciência Rural, v.39, n.3, mai-jun, 2009. 
Table 1 - Morphogenetic responses of leaves $\boldsymbol{V}$. reitzii cultured in MS culture medium free of PGR or supplemented with Dicamba and Kin, after 150 days in culture. CCA/UFSC, 2004.

\begin{tabular}{lc}
\hline CULTURE MEDIUM & SCORE \\
\hline MS PGR free & +++ \\
MS + Dicamba $(2,5 \mu \mathrm{M})+\operatorname{Kin}(2 \mu \mathrm{M})$ & ++ \\
MS + Dicamba $(5 \mu \mathrm{M})+\operatorname{Kin}(2 \mu \mathrm{M})$ & ++ \\
MS + Dicamba $(10 \mu \mathrm{M})+\operatorname{Kin}(2 \mu \mathrm{M})$ & ++ \\
MS + Dicamba $(20 \mu \mathrm{M})+\operatorname{Kin}(2 \mu \mathrm{M})$ & + \\
MS + Dicamba $(30 \mu \mathrm{M})+\operatorname{Kin}(2 \mu \mathrm{M})$ & + \\
\hline
\end{tabular}

$(+++)$ friable, granular and uniform nodular cluster cultures; $(++)$ compact callus, less uniform and presence of necrosis in the limit of $50 \% ;(+)$ compact callus with necrosis in a rate higher than 50 $\%$.

Microbuds were regenerated from plantlets of $\mathbf{V}$. friburgensis var. paludosa germinated in vitro in MS medium supplemented with NAA and BAP (ALVES \& GUERRA, 2001).

An advantage of nodule cultures as it was observed in bromeliads (ALVES et al., 2006) is the high regeneration rate. In the present research the resulting mean regenerative rate ( 39 shots $/ 0.03 \mathrm{~g}$ callus) is considerably higher than those observed in other bromeliads. Previously it was showed the induction and multiplication of shoots in $\mathbf{V}$. reitzii from protuberances (RECH FILHO et al., 2005). Also in this same species it was demonstrated the competence for long-term regeneration and multiplication of nodule clusters (ALVES et al., 2006).

In conclusion the results of the present work show the induction of $\boldsymbol{V}$. reitzii nodule cultures from the basal region of leaves inoculated in MS culture medium free of PGR. The transference of these cultures to MS medium with $\mathrm{GA}_{3}$ or free of PGR promoted the multiplication of adventitious shoots, and the development of plantlets. Plantlets higher than $2.5 \mathrm{~cm}$ were acclimatized. These results open new possibilities for the bromeliad mass propagation and conservation.

\section{REFERENCES}

ALVES, G.M. et al. Micropropagation of the Brazilian endemic bromeliad Vriesea reitzii trough nodule clusters culture. Scientia Horticulturae, Amsterdam, v.110, p.204-207, 2006.

ALVES, G.M.; GUERRA, M.P. Micropropagation for mass propagation and conservation of Vriesea friburgensis var. paludosa from microbuds. Journal of the Bromeliad Society, Orlando, v.51, n.5, p.202-212, 2001.

GEORGE, E.F. Plant propagation by tissue culture: the technology. Part 1. 2.ed. Edington: Exegetics, 1993. 574p.

MERCIER, H.; KERBAUY, G.B. In vitro multiplication of Vriesea fosteriana. Plant Cell, Tissue and Organ Culture, Dordrecht, v.30, p.247-249, 1992.

MURASHIGE, T.; SKOOG, F. A revised medium for rapid growth and biossays with tobacco tissue cultures. Physiologia Plantarum, Copenhagen, v.15, p.473-497, 1962.

POMPELLI, M.F.; GUERRA, M.P. Micropropagation enables the mass propagation of Dyckia distachya. Crop Breeding and Applied Biotechnology, Viçosa, v.5, p.117-126, 2005.

RECH FILHO, A. et al. Tissue culture for the conservation and mass propagation of Vriesea reitzii Leme and Costa, a bromeliad threatened of extinction from the Brazilian Atlantic Forest. Biodiversity and Conservation. Netherlands, v.14, p.1799$1808,2005$.

REITZ, R. Bromeliáceas e a malária - bromélia endêmica. (Flora ilustrada Catarinense série 983). Itajaí: Herbário Barbosa Rodrigues, 1983. 559p. 